\title{
Relasi Penerapan Elemen Interior Healing Environment Pada Ruang Rawat Inap dalam Mereduksi Stress Psikis Pasien (Studi Kasus: RSUD. Kanjuruhan, Kabupaten Malang)
}

\author{
Debri Haryndia Putri ${ }^{1}$, Widihardjo ${ }^{2} \&$ Andriyanto Wibisono $^{3}$ \\ ${ }^{1}$ Program Magister Desain, Fakultas Seni Rupa dan Desain, Institut Teknologi Bandung, \\ Jalan Ganesa No.10, Bandung 40132, Indonesia \\ ${ }^{2}$ KK Ilmu Desain dan Budaya Visual, Fakultas Seni Rupa dan Desain, Institut \\ Teknologi Bandung, Jalan Ganesa No.10, Bandung 40132, Indonesia \\ ${ }^{3}$ KK Manusia dan Lingkungan, Fakultas Seni Rupa dan Desain, Institut Teknologi \\ Bandung, Jalan Ganesa No.10, Bandung 40132, Indonesia \\ Email: debriputri@yahoo.com
}

\begin{abstract}
Abstrak. Suasana lingkungan medis yang menyenangkan merupakan lingkungan yang bisa membantu adaptasi proses penyembuhan pasien. Bagaimanapun, lingkungan medikal seringkali diidentifikasikan dengan hal yang menakutkan, menggelisahkan, dan ketidakpastian yang bisa menekan sistem imunisasi yang mengakibatkan pasien tinggal lebih lama dan bahkan bisa menimbulkan komplikasi selama masa penyembuhannya. Penelitian ini dimaksudkan untuk menganalisis bagaimana mengoptimalkan penerapan elemen interior healing environment (elemen sirkulasi, pencahayaan, warna dan elemen pendukung interior: unsur alam, fasilitas sosial dan televisi) dalam ruang perawatan pasien mempengaruhi aspek psikologis pasien. Penelitian dilaksanakan pada Rumah Sakit Umum Daerah Kanjuruhan, Kabupaten Malang yang memiliki kondisi fisik interior yang sesuai. Hasil penelitian menunjukkan bahwa lingkungan yang alami dan menggunakan pencahayaan yang alami memiliki potensi untuk mengurangi stres pasien, memberikan kondisi yang lebih baik bagi mereka yang dekat dengan alam. Perbedaan dalam latar belakang ekonomi, kultur, lingkungan sosial menghasilkan perbedaan persepsi pada cara pandang terhadap elemen penyembuhan pada pengaturan lingkungannya.
\end{abstract}

Kata kunci: elemen interior; healing environment; latar belakang sosial; pasien; psikologi; stres; unsur alam.

\begin{abstract}
The pleasing atmosphere of medical environment is a friendly atmosphere so it can accelerate the adaptation process of patients. However, the medical environment is very often identical with fear, anxiety, and uncertainty that can suppress the immune system so that patients require longer treatment time and even hasten the complications during treatment occur. This study is conducted to analyze how to optimize the application of healing environment interior elements (such: circulation, lighting, color, interior supporting elements: natural elements, the position of social interaction and television) inside the
\end{abstract}

Received September $3^{\text {rd }} 2012$, Revised November $7^{\text {th }}, 2013$, Accepted November $29^{\text {th }}, 2013$.

Copyright (C) 2013 Published by LPPM ITB, ISSN: 1978-3078, DOI: 10.5614/itbj.vad.2013.5.2.2 
treatment room directly affect the patients psychologically. The research is at Kanjuruhan public hospital which has simple and candid interior physical condition. The results demonstrates that the elements of nature and natural lighting are potential to reduce patient stress, given the daily conditions of people who tend to be close to nature. The differences in economic background, culture, and community demographics would produce a different perception in looking at the most ideal and suitable healing elements for their treatment environment.

Keywords: healing environment; interior elements; natural elements; patient; psychology; social background; stress.

\section{Pendahuluan}

Sebuah lingkungan fisik memiliki pengaruh pada pemikiran, perasaan, serta perilaku manusia. Sebagai sebuah lingkungan binaan, ruang merupakan stimulus (rangsangan dari luar) yang mampu direspon oleh sistem panca indera manusia (penglihatan, pendengaran, pengecap, penciuman, dan sentuhan), dimana secara psikologis berpotensi membentuk persepsi yang secara tidak langsung berpengaruh pada emosional serta perilaku manusia. Menurut Laurens [1], manusia normal dengan segala kelengkapan fisik dan psikis memungkinkan untuk menyesuaikan respon terhadap stimulus yang diterimanya dan ketika stimulus yang diterima berada di luar batas optimal, mereka dapat mengalami stress psikologis yang mengharuskannya melakukan proses adaptasi secara dinamis.

Hal tersebut akan sangat berbeda apabila terjadi pada seseorang yang sedang sakit, dimana kondisi fisik dan psikisnya berada di luar normal. Secara fisik, kondisi sistem indera seorang pasien mengalami kemunduran dalam merespon stimulus dari lingkungan sekitarnya akibat penyakit yang dideritanya. Keterbatasan fisik akibat sakit dapat menghambat proses adaptasi yang mereka lakukan ketika berhadapan dengan stimulus lingkungan yang berada di luar batas optimal.

Suasana lingkungan medis identik dengan ketakutan, kegelisahan, perasaan tertekan, serta ketidakpastian. Kegagalan proses adaptasi pasien terhadap lingkungan medis dapat menyebabkan stress psikologis dalam diri pasien yang berpengaruh terhadap proses penyembuhannya [2]. Pernyataan tersebut diperkuat oleh Dijkstra [3] yang mengungkapkan bahwa efek fisiologis dari sebuah lingkungan fisik sangat berpengaruh pada hasil penyembuhan, dimana terdapat sebuah korelasi yang positif antara elemen-elemen lingkungan dengan hasil penyembuhan. Secara medis, stress psikologis yang terjadi pada pasien dapat menekan sistem imun sehingga pasien memerlukan waktu perawatan yang lebih lama dan bahkan dapat mempercepat terjadinya komplikasikomplikasi selama perawatan [4]. Fakta medis tersebut menunjukkan peran 
rumah sakit secara umum, serta ruang rawat inap secara khusus sebagai sebuah lingkungan perawatan cukup esensial dalam mereduksi stress psikologis pada diri pasien.

Konsep healing environment pada lingkungan rumah sakit ditujukan untuk menyeimbangkan intervensi ilmu dan teknologi medik dengan potensi internal pasien. Menurut Dijkstra [3], healing environment adalah lingkungan fisik fasilitas kesehatan yang dapat mempercepat waktu pemulihan kesehatan pasien atau mempercepat proses adaptasi pasien dari kondisi kronis serta akut dengan melibatkan efek psikologis pasien di dalamnya. Penerapan konsep healing environment pada lingkungan perawatan akan tampak pada kondisi akhir kesehatan pasien, yaitu pengurangan waktu rawat, pengurangan biaya pengobatan, pengurangan rasa sakit, pengurangan stres atau perasaan tertekan, memberikan suasana hati yang positif, membangkitkan semangat, serta meningkatkan pengharapan pasien akan lingkungan.

Sebagai penyedia layanan kesehatan umum, banyak pengelola rumah sakit yang beranggapan bahwa proses pemulihan kesehatan hanya dapat dilakukan dengan jalan medis [5]. Kenyataan tersebut juga kerap terjadi di Indonesia, dimana masih sedikit pihak pengelola rumah sakit yang menganggap pentingnya penerapan konsep healing environment yang memprioritaskan kenyamanan psikologis pasien sebagai bagian esensial dari proses penyembuhan pasien. Kalaupun ada, itupun masih sangat sedikit dan terbatas hanya pada rumah sakit swasta serta rumah sakit pemerintah di Jakarta serta ibukota propinsi yang memiliki segmentasi pasar masyarakat golongan ekonomi menengah-atas. Rumah sakit umum pemerintah di daerah yang cenderung memiliki segmentasi pasar golongan masyarakat menengah-bawah seperti RSUD Kanjuruhan, Kabupaten Malang, dirancang dengan standar yang cenderung hanya memperhatikan sisi fungsionalnya saja, padahal masyarakat kecil juga memiliki hak yang sama untuk memperoleh proses pemulihan kesehatan yang manusiawi. Kondisi ruang rawat inap rumah sakit ini belum cukup optimal dalam mewadahi kebutuhan psikis pasien, karena terbatasnya dana serta minimnya pengetahuan pemerintah daerah serta praktisi desain akan pentingnya berbagai stimulus positif dalam lingkungan perawatan.

Melihat fenomena yang telah dijelaskan diatas, penelitian ini dilakukan sebagai sebuah pembuktian bahwa lingkungan fisik secara nyata memiliki relasi yang cukup kuat dalam mempengaruhi psikologis manusia. Penelitian bertujuan memberikan rekomendasi konsep desain bagi para praktisi dalam menetapkan prioritas dalam memilih variabel healing yang bisa diterapkan mengingat keterbatasan dana yang sering dialami oleh rumah sakit pemerintah. Pemilihan ruang rawat inap VIP RSUD Kanjuruhan sebagai obyek studi kasus diharapkan 
dapat memberikan gambaran yang jelas bagi para praktisi desain, pemerintah serta masyarakat bahwa dengan dana yang terbatas serta pemilihan elemen healing environment yang tepat dapat membantu meningkatkan mutu pelayanan rumah sakit itu sendiri.

\section{$2 \quad$ Metode Penelitian}

Penelitian mengenai relasi penerapan elemen interior healing environment pada ruang rawat inap dalam mereduksi stress psikis yang dialami pasien merupakan penelitian kualitatif dengan pendekatan psikometri. Menurut Noor [6], psikometri adalah cabang ilmu psikologi yang mempelajari tentang pengukuran perilaku yang meliputi konsep, teknik, dan metode pengukuran perilaku dalam upaya memahami perilaku manusia. Pada penelitian ini, obyek pengukurannya adalah perilaku stress yang dialami oleh pasien ketika berada di dalam ruang rawat inap, sedangkan parameter pengukurannya adalah elemen-elemen visual healing environment yang meliputi sirkulasi, pencahayaan, warna, elemenelemen pendukung interior seperti elemen alam, posisi fasilitas interaksi sosial dan posisi fasilitas televisi.

Metode kualitatif digunakan pada penelitian ini karena dinilai mampu menganalisa realitas psikologi yang terjalin antara ruang sebagai lingkungan binaan dengan manusia sebagai penggunanya secara lebih mendalam. Penelitian ini memerlukan tiga buah jenis data yaitu data teoritis yang didapatkan dari studi literatur, data visual yang didapatkan dari observasi penulis pada kondisi lapangan, serta data psikometri yang merupakan gambaran penilaian pasien terhadap kondisi fisik lingkungan perawatan yang didapatkan penulis dari hasil kuesioner. Data literatur pada penelitian ini difokuskan pada kriteria ideal healing environment. Pada tahap analisis, data literatur dibandingkan dengan data visual sehingga didapatkan gambaran keidealan penerapan elemen healing evironment pada ruang rawat inap VIP RSUD. Kanjuruhan. Hasil data tersebut akan dibandingkan dengan data psikometri yang sebelumnya telah diolah dengan perhitungan statistika secara sederhana sehingga didapatkan penilaian terhadap kenyamanan yang dirasakan oleh pasien secara psikis terutama berkaitan dengan kemampuan elemen-elemen tersebut mereduksi stress pasien.

\section{Hasil dan Pembahasan}

Konsep healing environment yang merupakan salah satu konsep pembentukkan lingkungan perawatan yang memadukan aspek fisik serta psikologis pasien di dalamnya yang bertujuan untuk mempercepat proses adaptasi pasien sehingga dengan keterbatasan fisiknya seorang pasien dapat beradaptasi dengan cepat yang berdampak pada menurunnya tingkat stress pasien akibat lingkungan fisik rumah sakit. Pada penelitian ini elemen-elemen healing environment yang akan 
dibahas antara lain: elemen sirkulasi, elemen pencahayaan, elemen warna, elemen alam, posisi fasilitas interaksi sosial, serta posisi fasilitas televisi.

\subsection{Sirkulasi}

Kondisi sirkulasi pada instalasi rawat inap VIP RSUD. Kanjuruhan belum sesuai dengan kriteria ideal pada studi teoritis. Penerapannya yang belum ideal ini juga mendapatkan penilaian tidak nyaman dari sudut pandang pasien, karena itu dapat disimpulkan bahwa penerapan elemen sirkulasi yang tidak ideal pada rumah sakit ini menyebabkan pasien merasa tidak nyaman akibat takut bergerak dan takut tersesat dalam lingkungan perawatan yang terasa asing baginya. Perasaan takut yang dialami pasien tanpa disadari dapat menyebabkan stress psikis yang dapat menghambat proses pemulihan kesehatannya.

\subsection{Elemen Pencahayaan}

Hasil analisa penulis berdasarkan studi teoritis terhadap penerapan elemen pencahayaan memiliki kesesuaian dengan apa yang dirasakan pasien ketika berhadapan dengan elemen cahaya dalam ruang rawat inap VIP ini. Para pasien merasa pencahayaan alami yang masuk ke dalam ruangan ini cukup nyaman bagi mata mereka. Di sisi lain, mereka merasa tidak nyaman akan penerapan pencahayaan buatan dalam ruang rawat inap ini. Hal tersebut sesuai dengan analisa penulis mengenai penerapan elemen pencahayaan buatan pada area koridor, pos perawat, serta yang tidak sesuai dengan kriteria ideal healing environment. Posisi sumber pencahayaan buatan yang terlihat langsung oleh mata pasien menimbulkan kesilauan yang menyebabkan pasien sering merasa susah tidur ketika malam yang berpotensi menyebabkan stress psikis dan dapat menghambat proses pemulihan kesehatannya.

\subsection{Elemen Warna}

Penerapan elemen warna pada ruang rawat inap secara umum telah sesuai dengan kriteria ideal healing environment, namun, visualisasi ruang yang terang dengan menggunakan nada warna putih dan hijau ini dirasa tidak nyaman oleh pasien. Hal tersebut disebabkan karena kesan ruang rawat inap yang dingin dan monoton yang diciptakan oleh penggunaan warna hijau pada dinding dan furniture serta warna putih pada lantai dan langit-langitnya. Penggunaan material keramik pada dinding menambah dinginnnya ruang rawat inap VIP ini. Kondisi temperatur Malang yang cukup dingin ditambah dengan kesan ruang rawat inap yang dingin berpotensi menyebabkan stress dalam diri pasien. Berdasarkan pengamatan penulis, pasien membutuhkan suasana ruang rawat dengan kesan hangat dan bersahabat melalui pengkombinasian warna-warna dingin tersebut dengan warna-warna dalam skema warna hangat sebagai warna 
aksen untuk mereduksi perasaan "dingin" yang dirasakan pasien ketika berada dalam ruang rawat inap, dengan begitu ia tidak merasa asing dan merasa lebih diterima ketika berada dalam ruang rawat inap.

\subsection{Elemen Alam}

Penerapan elemen alam pada rumah sakit berupa pemandangan taman yang masuk melalui jendela-jendela kamar telah sesuai dengan kriteria ideal sebuah healing environment. Elemen ini dinilai cukup positif dalam mereduksi stress pasien yang dibuktikan oleh hasil kuesioner yang menyatakan bahwa mayoritas pasien pada ruang rawat inap ini merasa bahwa penerapan elemen alam berupa pemandangan taman dari jendela ruang rawat mereka dapat menjadi elemen healing environment yang efektif dalam mereduksi stress yang mereka rasakan. Posisi tempat tidur pasien yang berdekatan dengan jendela besar dirasa cukup maksimal bagi para pasien VIP RSUD. Kanjuruhan untuk menikmati akses alam dari atas tempat tidurnya.

\subsection{Fasilitas Interaksi Sosial}

Keberadaan fasilitas interaksi sosial di dalam ruang rawat inap ini belum sesuai dengan kriteria ideal sebuah healing environment. Hasil analisa tersebut juga dirasakan oleh pasien. Para pasien merasa kurang nyaman dengan penempatan posisi furniture yang diperkuat oleh hasil kuesioner yang menyatakan bahwa pasien-pasien yang dirawat pada ruang rawat inap VIP ini mengalami kesulitan dalam mengakses fasilitas interaksi sosial tersebut yang berpotensi menambah stress yang mereka alami akibat keterbatasan dalam melakukan interaksi sosial dengan keluarga serta penjenguknya. Posisi fasilitas interaksi sosial ini harus mudah dijangkau oleh mata pasien, namun tetap memperhatikan privasi pasien untuk beristirahat. Elemen furniture yang mewadahi fungsi sosial pada koridor serta dalam kamar pasien sangatlah penting keberadaannya. mengingat budaya dan kebiasaan masyarakat Indonesia yang memiliki ikatan kekeluargaan yang cukup tinggi. Keberadaan fasilitas ini memberikan kesempatan bagi keluarga pasien untuk menunggui pasien, berinteraksi dan memberikan dukungan sosial bagi pasien sehingga pasien tidak merasa sendiri dalam menjalani proses rawat inap.

\subsection{Elemen Televisi}

Penerapan fasilitas televisi tidak sesuai dengan kriteria ideal penerapan elemen healing environment, hal tersebut sejalan dengan pernyataan pasien mengenai ketidaknyamanan yang dirasakan pasien akibat kesulitan pasien dalam mengakses visual televisi dari atas tempat tidur. Apabila kondisi tersebut dibiarkan terus-menerus terjadi dapat mengurangi rasa percaya diri pasien akan kemampuannya mengontrol ruangan yang pada akhirnya akan menambah stress 
psikis dalam dirinya. Untuk itu dapat dilakukan beberapa cara agar posisi televisi dapat diakses secara mudah oleh pasien dari atas tempat tidur antara lain meletakkan televisi pada rak televisi yang lebih tinggi dari posisi tempat tidur atau meletakkan televisi dengan cara digantung ke langit-langit atau pada dinding bagian atas.

Dari uraian di atas dapat ditarik beberapa hasil pembahasan dalam tiga kriteria atau kelompok, yaitu:

1. Kelompok elemen interior healing environment yang ideal dan nyaman bagi pasien mencakup elemen alam dan elemen pencahayaan alami.

2. Kelompok elemen interior healing environment yang ideal namun tidak nyaman bagi pasien yaitu elemen warna.

3. Kelompok elemen interior healing environment yang tidak ideal serta tidak nyaman bagi pasien mencakup elemen sirkulasi, elemen pencahayaan buatan, posisi fasilitas interaksi sosial, serta posisi televisi.

\section{$4 \quad$ Kesimpulan}

Penelitian ini merupakan salah satu pembuktian bahwa ruang interior memiliki pengaruh pada pemikiran, perasaan, serta perilaku manusia. Suasana lingkungan fisik rawat inap VIP RSUD. Kanjuruhan identik dengan ketakutan, kegelisahan, perasaan tertekan, serta ketidakpastian yang berpotensi menimbulkan stress dalam diri pasien. Kondisi stress ini diakui oleh pasien dapat diminimalisir melalui penerapan elemen-elemen healing environment dalam interior ruang rawat inap. Konsep healing environment yang merupakan salah satu konsep pembentukkan lingkungan perawatan yang memadukan aspek fisik dan psikologis pasien di dalamnya yang bertujuan untuk mempercepat proses adaptasi pasien sehingga dengan keterbatasan fisiknya seorang pasien dapat beradaptasi dengan cepat yang berdampak pada menurunnya tingkat stress. Berdasarkan analisis yang telah dilakukan, maka dapat disimpulkan:

1. Elemen alam dan pencahayaan alami merupakan elemen healing environment yang bisa mereduksi stress pasien.

2. Latar belakang ekonomi, kultur dan demografi akan menghasilkan persepsi yang berbeda terhadap elemen healing environment yang ideal dan sesuai bagi mereka.

Berdasarkan kesimpulan penerapan elemen interior healing environment dalam mereduksi stress pasien yang mengambil studi kasus ruang rawat inap VIP RSUD Kanjuruhan, Kabupaten Malang dengan dasar studi teoritis serta hasil persepsi pasien, maka dalam perencanaan penerapan elemen interior healing 
environment dalam instalasi ruang rawat inap rumah sakit di Malang direkomendasikan beberapa konsep desain, antara lain:

Penerapan elemen sirkulasi pada instalasi rawat inap yang ideal dapat dicapai melalui beberapa hal:

1. Penerapan pola sirkulasi linier bercabang pada area koridor akan memudahkan pasien untuk menentukan ruang yang dituju serta memudahkan mereka untuk bergerak di dalam rumah sakit tanpa takut tersesat.

2. Penggunaan koridor utama yang tertutup secara fisik dan terbuka secara visual lebih disarankan sehingga sinar matahari serta pemandangan taman dapat tampak langsung oleh mata pasien. Koridor instalasi rawat inap sebaiknya tertutup secara fisik dan visual untuk menjamin kesterilannya. Keberadaan koridor tersebut harus diperlengkapi dengan elemen pengaman seperti pegangan pada dindingnya sehingga keamanan pasien pada area sirkulasi tetap terjamin.

3. Posisi pos perawat harus mampu menjangkau seluruh ruang rawat inap yang ada, oleh karena itu bentuk sirkulasi yang sesuai adalah koridor tunggal dengan peletakkan pos perawat di tengah-tengah area koridor. Jarak ideal pos perawat terhadap ruang rawat inap terjauh \pm 20 meter. Rute sirkulasi yang pendek tersebut dapat mempermudah aktivitas medis dan non-medis yang berlangsung pada rumah sakit tersebut, selain itu peletakkan pos perawat pada tengah koridor akan memudahkan para perawat mengawasi para pasien serta pengunjung yang melintasi area koridor.

4. Dimensi besaran koridor ideal yang mampu menampung pergerakkan dua buah tempat tidur dorong serta memudahkan perputaran tempat tidur masuk ke dalam ruang rawat inap adalah $2.500 \mathrm{~mm}$. Dimensi lebar koridor yang ideal tersebut secara efektif dapat menunjang kinerja perawat dalam memberikan pelayanan medis kepada pasien.

5. Sirkulasi dalam ruang rawat inap harus memperhatikan kebutuhan serta keterbatasan fisik pasien. Untuk memudahkan sirkulasi bagi pasien dalam ruang rawat inap, jarak tempat tidur dengan dinding, jendela atau furniture lain minimal $900 \mathrm{~mm}$ dari posisi tempat tidur. Keberadaan jarak tersebut bertujuan agar furniture tidak mengganggu alur sirkulasi pasien dan keluarga pasien dalam ruang rawat inap.

6. Sirkulasi pasien menuju kamar mandi sebaiknya tidak terhalangi oleh furniture sebab dengan keterbatasan fisiknya, seorang pasien membutuhkan ruang gerak yang lebih besar mengingat kebutuhannya untuk ditolong oleh orang lain ketika melakukan aktivitas ini. 
7. Dimensi ruang sirkulasi dalam ruang rawat inap yang ideal berkisar antara $25 \%$ hingga $40 \%$ dari luasan ideal ruang rawat inap single bed yaitu $10 \mathrm{~m}^{2}$, sehingga, sirkulasi yang ideal dalam sebuah ruang rawat inap berkisar antara 2,5 $\mathrm{m}^{2}$ hingga $4 \mathrm{~m}^{2}$ untuk setiap kamarnya. Keberadaan dimensi ruang sirkulasi yang ideal dapat mempermudah pergerakkan pasien di dalam ruang rawat inap sehingga stress pasien dapat tereduksi.

8. Ruang rawat inap sebaiknya memiliki satu entrance. Main entrance sebaiknya menggunakan daun pintu ganda dengan ukuran $2.000 \mathrm{~mm} \mathrm{x}$ $(900+500) m m$ yang dapat memudahkan sirkulasi tempat tidur dorong pasien keluar masuk ruangan.

Penerapan elemen pencahayaan pada instalasi rawat inap yang ideal dapat dicapai melalui beberapa hal:

1. Pencahayaan alami yang ideal dapat dicapai dengan memberikan bukaan berupa jendela yang letaknya sejajar dengan posisi tempat tidur pasien dengan jarak sekitar $900 \mathrm{~mm}$. Posisi tersebut dapat mengurangi kilauan cahaya matahari, sehingga sinar matahari dapat masuk secara maksimal ke dalam ruang rawat inap namun tidak menyilaukan mata pasien. Lebar jendela yang ideal minimal berukuran $1.000 \mathrm{~mm}$ dengan tinggi bervariasi.

2. Posisi jendela dalam ruang rawat inap yang ideal sebaiknya hanya pada salah satu sisi dinding ruangnya sehingga cahaya matahari tetap masuk secara maksimal ke dalam ruang rawat inap namun tidak membawa panas yang berlebih.

3. Pencahayaan buatan yang ideal dalam ruang rawat inap sebaiknya menggunakan tiga buah jenis pencahayaan buatan yaitu pencahayaan untuk aktivitas pemeriksaan, pencahayaan untuk aktivitas personal pasien serta pencahayaan general. Posisi ketiga buah sumber pencahayaan buatan ini harus terlindung dari mata pasien misalnya sumber pencahayaan ditanam di langit-langit (mounted downlight) atau disembunyikan di samping langitlangit (hidden lamp). Posisi lampu tersebut diyakini dapat memberikan kenyamanan visual bagi pasien.

4. Posisi pencahayaan buatan pada ruang rawat inap tidak boleh berada persis di atas kepala pasien sehingga pasien dapat beristirahat dengan mudah.

5. Ruang rawat inap harus memampukan pasien mengontrol pencahayaan dalam ruang rawat. Peletakkan saklar lampu yang ideal berkisar \pm 1.300 $\mathrm{mm}$ dari permukaan lantai. Posisi saklar lampu tersebut akan memudahkan pasien mengontrol pencahayaan buatan dari atas tempat tidurnya.

6. Adanya pembagian kontrol terhadap pencahayaan buatan yang mudah dijangkau pasien pada ruang rawat inap, sehingga pasien dapat beristirahat dengan tenang ketika malam. 
7. Penerangan general pada area koridor dan pos perawat sebaiknya ditanam di dalam langit-langit (mounted downlight), atau menurunkan ketinggian langit-langit kemudian meletakkan lampu di sisi samping langit-langit (hidden lamp) sehingga cahaya lampu yang dilihat oleh pasien berupa pendaran. Posisi lampu yang tidak tampak oleh mata pasien tersebut bertujuan mengurangi kesilauan mata pasien dan staf medis.

Penerapan elemen warna yang ideal dapat dicapai melalui melalui beberapa hal:

1. Menurut teori, warna yang sesuai bagi ruang rawat inap adalah warna hijau pastel dan biru pastel. Namun, ternyata warna hijau pastel ini tidak efektif diterapkan pada ruang rawat inap rumah sakit ini. Warna hijau merupakan warna yang cukup dekat dengan masyarakat Malang yang wilayahnya sebagian besar merupakan pegunungan, namun pemilihan warna hijau pastel dan putih tersebut ternyata menambah kesan "dingin" di dalam ruang rawat inap. Kondisi tersebut memerlukan penyesuaian sehingga ruang rawat inap tidak berkesan terlalu dingin namun tetap tampak bersahabat antara lain:

a. Penggunaan warna hangat yang lembut seperti krem $(c=1, m=0, y=20$, $\mathrm{k}=0$ ), diletakkan pada keseluruhan permukaan dinding dengan persentase $80 \%$. Warna ini digunakan untuk mengganti warna putih yang sering menimbulkan kejenuhan dalam diri pasien. Garis pembatas yang mulanya berwarna biru sebaiknya menggunakan warna coklat yang merupakan warna asli material pembatas dinding tersebut.

b. Permainan komposisi warna pada dinding diperlukan untuk mengurangi kemonotonan dalam ruang rawat inap. Permainan komposisi warna ini dapat dilakukan dengan memberikan warna aksen yang berbeda namun tidak terlalu kontras pada salah satu dindingnya sehingga ruangan tidak berkesan monoton. Warna aksen yang digunakan pada dinding ruang rawat inap adalah warna hijau pastel yang bernuansa alam dan merilekskan sehingga membantu mengurangi ketegangan pasien.

c. Warna furniture yang sesuai dengan warna dinding ruangan adalah warna coklat. Penggunaan furniture dengan warna coklat $(\mathrm{c}=30, \mathrm{~m}=55$, $\mathrm{y}=100, \mathrm{k}=13$ ) dapat mengimbangi kesan dingin yang ditimbulkan oleh warna hijau pada dinding ruangnya.

d. Warna langit-langit dan lantai ruang rawat inap sebaiknya menggunakan warna coklat muda ( $c=33, \mathrm{~m}=35, \mathrm{y}=50, \mathrm{k}=1$ ) yang memiliki daya pantul yang tinggi sehingga ruang rawat inap tetap tampak terang.

e. Penggunaan warna pada area koridor yang ideal adalah warna cerah seperti kuning keemasan, orange labu, biru turquoise, dan hijau rumput. Warna-warna tersebut disarankan memiliki value 5-10 (warna-warna pastel) dan diletakkan sebagai warna dominan pada dinding ruangan. 
Untuk menghadirkan warna tersebut sebagai aksen dalam ruangan maka intensitas warna tinggi yang dipilih, namun apabila menginginkan warna tersebut sebagai warna dominan, maka warna yang dipilih menggunakan intensitas rendah. Lantai dan langit-langit sebaiknya menggunakan warna-warna muda dengan daya pantul tinggi sehingga area koridor tampak terang.

Elemen alam pada instalasi rawat inap rumah sakit di daerah merupakan elemen yang paling potensial dalam mereduksi stres pasien.. Oleh karena itu, sebuah lingkungan rawat inap yang ideal harus menyediakan akses menuju alam secara maksimal antara lain:

1. Menyediakan bukaan berupa jendela yang dapat memberikan akses pemandangan taman secara optimal. Peletakkan tempat tidur pasien diusahakan berjarak $900 \mathrm{~mm}$ dari jendela sehingga pasien dapat menikmati pemandangan taman secara langsung.

2. Apabila kondisi instalasi rawat inap tidak memiliki akses menuju taman secara langsung, keberadaan elemen alam dalam lingkungan rawat inap dapat terwujud melalui elemen alam artificial seperti lukisan pemandangan alam, atau karya seni tentang alam, dan lain sebagainya.

Posisi fasilitas interaksi sosial harus dapat diakses langsung oleh pasien dari posisi di atas tempat tidur. Posisi fasilitas ini memiliki jarak ideal sekitar 900 $\mathrm{mm}$ dari tempat tidur pasien. Posisi fasilitas interaksi sosial tidak boleh terhalangi oleh furniture lain, dengan begitu, pasien dapat merasa tenang ketika dirinya dapat melihat keluarganya berada di dalam ruang rawat inap mendukung proses kesembuhan yang sedang dijalaninya.

Posisi televisi yang ideal harus dapat diakses langsung oleh pasien dari posisi tempat tidur pasien. Untuk itu posisi yang sesuai bagi peletakkan televisi ini adalah dengan cara digantung ke dinding atau langit-langit dan diarahkan ke tempat tidur pasien dengan ketinggian yang diperkirakan berada dalam jangkauan sudut pandang ideal mata pasien sekitar $15^{\circ}$. Posisi televisi tersebut memudahkan pasien dapat menikmati fasilitas televisi dengan mudah dari atas tempat tidur pasien. Pemilihan televisi yang sesuai dengan peletakkan tersebut berjenis LCD berukuran minimal 21 inch dikarenakan televisi jenis ini sangat ringan sehingga mudah untuk digantung di langit-langit atau dinding.

Dari paparan rekomendasi desain penerapan elemen interior healing environment di atas maka diusulkanlah lay-out ruang rawat inap VIP yang ideal serta nyaman bagi pasien, yaitu: 

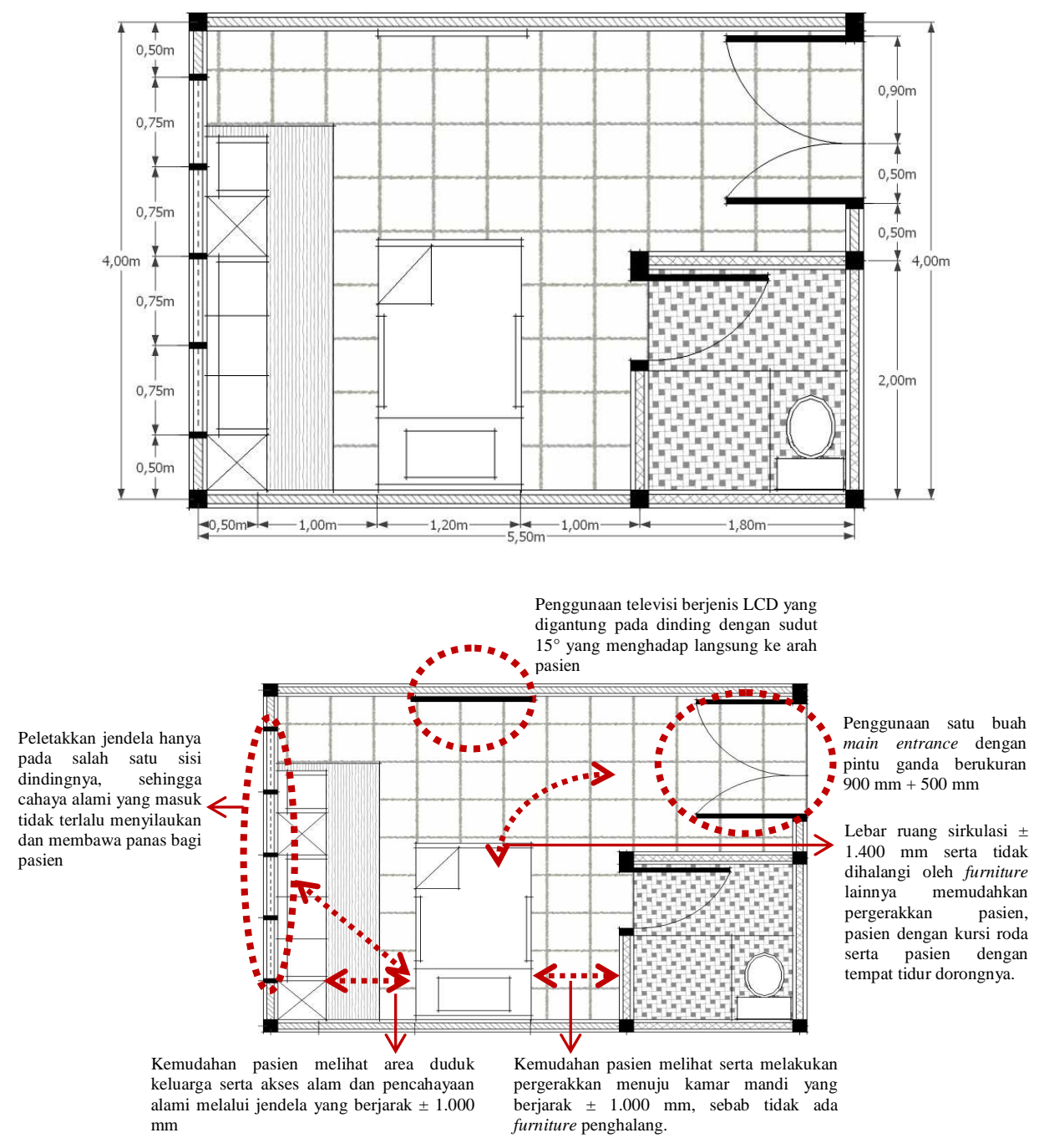

Gambar 1 Rekomendasi lay-out ruang rawat inap VIP yang ideal dan nyaman bagi pasien. Sumber: Dok. Pribadi, 2011.

\section{References}

[1] Laurens, J.M. 2004. Arsitektur dan Perilaku Manusia, Jakarta: Grasindo.

[2] Putri, L. (dr.). 2011. Wawancara, Malang. 
[3] Djikstra, K. 2009. Understanding Healing Environments: Effects of Physical Environmental Stimuli on Patiens' Effects of Health and WellBeing, Netherlands: University of Twente.

[4] Dani, S. 2004. Mekanisme Percepatan Pemulihan Keradangan karena Rasa Senang. Surabaya: Universitas Airlangga.

[5] Kaplan, R.M., Sallis, J.M., Jr. \& Patterson, T.L. 1993. Health and Human Behavior. New York: Mc. Graw Hill Inc.

[6] Noor, H. 2009. Psikometri, Aplikasi dalam Penyusunan Instrumen Pengukuran Perilaku, Bandung: Fakultas Psikologi Unisba. 